\title{
Aquaporin-4 Water Channel Protein in the Rat Retina and Optic Nerve: Polarized Expression in Müller Cells and Fibrous Astrocytes
}

\author{
Erlend A. Nagelhus, ${ }^{1}$ Margaret L. Veruki, ${ }^{2}$ Reidun Torp, ${ }^{1}$ Finn-M. Haug, ${ }^{1}$ Jon H. Laake, ${ }^{1}$ Søren Nielsen, ${ }^{3}$ \\ Peter Agre, ${ }^{4}$ and Ole P. Ottersen ${ }^{1}$ \\ Departments of ${ }^{1}$ Anatomy and ${ }^{2}$ Neurophysiology, Institute of Basic Medical Sciences, University of Oslo, N-0317 Oslo, \\ Norway, ${ }^{3}$ Department of Cell Biology, Institute of Anatomy, University of Aarhus, DK-8000 Aarhus, Denmark, and \\ ${ }^{4}$ Departments of Biological Chemistry and Medicine, The Johns Hopkins University School of Medicine, Baltimore, \\ Maryland 21205
}

The water permeability of cell membranes differs by orders of magnitude, and most of this variability reflects the differential expression of aquaporin water channels. We have recently found that the CNS contains a member of the aquaporin family, aquaporin-4 (AQP4). As a prerequisite for understanding the cellular handling of water during neuronal activity, we have investigated the cellular and subcellular expression of AQP4 in the retina and optic nerve where activity-dependent ion fluxes have been studied in detail. In situ hybridization with digoxigenin-labeled riboprobes and immunogold labeling by a sensitive postembedding procedure demonstrated that AQP4 and AQP4 mRNA were restricted to glial cells, including Müller cells in the retina and fibrous astrocytes in the optic nerve. A quantitative immunogold analysis of the Müller cells showed that these cells exhibited three distinct membrane compartments with regard to AQP4 expression. End feet membranes (facing the vitreous body or blood vessels) were 10-15 times more intensely labeled than non-end feet membranes, whereas microvilli were devoid of AQP4. These data suggest that Müller cells play a prominent role in the water handling in the retina and that they direct osmotically driven water flux to the vitreous body and vessels rather than to the subretinal space. Fibrous astrocytes in the optic nerve similarly displayed a differential compartmentation of AQP4. The highest expression of AQP4 occurred in end feet membranes, whereas the membrane domain facing the nodal axolemma was associated with a lower level of immunoreactivity than the rest of the membrane. This arrangement may allow transcellular water redistribution to occur without inducing inappropriate volume changes in the perinodal extracellular space.

Key words: aquaporin; water homeostasis; potassium buffering; Müller cells; fibrous astrocytes; retina
Neuronal activity is characterized by net ion fluxes between different cellular and extracellular compartments (for review, see Syková, 1991; Deitmer and Rose, 1996; Newman and Reichenbach, 1996; Ransom and Orkand, 1996). Such fluxes inevitably give rise to osmotic gradients that will induce water redistribution (Lipton, 1973; Dietzel et al., 1980, 1982; Connors et al., 1982; Ransom et al., 1985; Syková, 1987, 1991; Svoboda and Syková, 1991; Andrew and MacVicar, 1994; Li et al., 1994a; Holthoff and Witte, 1996). Water redistribution is not trivial, because the accompanying volume changes may directly affect cellular function. For example, the swelling of neurons could alter the cable properties of their dendrites and change the electrotonic distance to distal synaptic inputs (Rall, 1977; Chebabo et al., 1995).

A major challenge for cellular volume control mechanisms is posed by the substantial efflux of $\mathrm{K}^{+}$during neuronal activity (Syková, 1991). Because the CNS possesses a narrow extracellular space, the excess extracellular $\mathrm{K}^{+}$cannot always be efficiently cleared by simple diffusion but will have to be buffered by uptake

Received Dec. 1, 1997; revised Jan. 20, 1998; accepted Jan 21, 1998.

This work was supported by the Norwegian Research Council, Professor Letten F. Saugstad's Fund, Rakel and Otto Kr. Bruun's fund, the National Institutes of Health, and European Union Biomed Programme Grant BMH4-CT96-0851. We thank Bjørg Riber, Karen Marie Gujord, Jorunn Knutsen, Hilde Raanaas, Gunnar Lothe, Carina Knudsen, Kari Ruud, Even O. Andersen, and Thorolf Nordby for excellent technical assistance.

Correspondence should be addressed to Erlend A. Nagelhus, Department of Anatomy, Institute of Basic Medical Sciences, University of Oslo, P.O. Box 1105 Blindern, N-0317 Oslo, Norway.

Copyright (C) 1998 Society for Neuroscience $\quad 0270-6474 / 98 / 182506-14 \$ 05.00 / 0$ into a cellular compartment (Gardner-Medwin, 1993a,b). Glial cells figure prominently in this regard and have been shown to remove excess $\mathrm{K}^{+}$from the extracellular cleft by active and passive uptake as well as by $\mathrm{K}^{+}$spatial currents (for review, see Walz, 1989; Newman, 1995; Amédée et al., 1997). The latter two mechanisms for $\mathrm{K}^{+}$removal tend to cause a reduction in extracellular osmolarity, presenting an osmotic challenge to glial cells as well as to neurons (Dietzel et al., 1989). A priori it would be expected that the nervous system is equipped with mechanisms that can direct the ensuing water flux in such a way as to minimize interference with neuronal function.

The plasma membranes of all mammalian cells are permeable to water, but to a different extent (Finkelstein, 1987). For instance, the kidney proximal tubules and descending thin limbs are exceptionally water-permeable, whereas the ascending thin and thick limbs resist water flux (Knepper and Rector, 1991). The highly water-permeable parts of the tubules have been shown to contain aquaporins (Fushimi et al., 1993; Nielsen et al., 1993a, 1995a,b; Echevarria et al., 1994; Ishibashi et al., 1994; Ma et al., 1994; Ecelbarger et al., 1995; Frigeri et al., 1995; Sabolic et al., 1995; Terris et al., 1995) (for review, see Nielsen and Agre, 1995), which represent a class of membrane molecules that mediate rapid water flux driven by osmotic gradients (Chrispeels and Agre, 1994). Thus the differentiated expression of aquaporins along the kidney tubules accounts for the observed variations in water permeability that are a prerequisite for the countercurrent-based concentration mechanisms and for vasopressin regulation of body water balance (Nielsen and Agre, 1995). 
Aquaporins also facilitate water flux through absorptive and secretory epithelia in other organs (for review, see Agre et al., 1995).

One of the members of the aquaporin family, aquaporin-4 (AQP4), was recently found to be preferentially expressed in the CNS (Hasegawa et al., 1994; Jung et al., 1994). Light and electron microscopic immunocytochemical analyses revealed that this protein was concentrated at interfaces between brain and liquor spaces and between brain and vessels (Nielsen et al., 1997a). It was speculated that AQP4 is engaged in volume homeostasis in the brain, a function that is of critical importance given the rigid encasement of this organ.

It was also proposed that AQP4 might have important roles at the cellular level. One possibility is that AQP4 directs osmotically driven water flux in the CNS, as other aquaporins do in the kidney. In this study we investigated whether the expression of AQP4 in the retina and optic nerve is compatible with such a hypothesis, which would presuppose a heterogeneous cellular and subcellular expression of this aquaporin. Detailed analyses of the activity dependent ion fluxes and water redistribution have been performed in the retina and optic nerve (Steinberg et al., 1980; Connors et al., 1982; Dick and Miller, 1985; Dick et al., 1985; Karwoski et al., 1985, 1989; Ransom et al., 1985; Coles, 1986; Coles et al., 1986; Nilius and Reichenbach, 1988; Reichenbach, 1991; Frishman et al., 1992; Reichenbach et al., 1992; Li et al., 1994a; Newman, 1996; Ransom and Orkand, 1996), allowing correlations to be made with aquaporin distribution. A more direct testing of AQP4 function will have to await the development of specific inhibitors.

\section{MATERIALS AND METHODS}

Animals. Male Wistar and PVG rats weighing between 250 and $300 \mathrm{gm}$ (Møllegaard, Ejby, Denmark) were used in this study. The animals were allowed ad libitum access to food and drinking water.

Antibodies. Six affinity-purified antisera, each recognizing a single aquaporin isoform (AQP1-5), were used. The antibodies were raised in rabbits against synthetic peptides and have been characterized in detail in other reports [anti-AQP1 LL266 (Terris et al., 1996), anti-AQP2 LL127 (Nielsen et al., 1993b), anti-AQP3 LL178 (Ecelbarger et al., 1995), anti-AQP4 LL182 and LL179 (Terris et al., 1995), and anti-AQP5 (Nielsen et al., 1997b)]. The two antibodies to AQP4 were directed to different parts of this molecule (amino acids 251-269 and 280-296 for antibodies LL179 and LL182, respectively).

Electrophoresis and immunoblotting. Membrane fractions were prepared from rat cerebellum and from dissected retina and ciliary body of rat eye. The tissue was isolated, minced finely, and homogenized in $10 \mathrm{ml}$ of dissecting buffer $(0.3 \mathrm{~m}$ sucrose, $25 \mathrm{~mm}$ imidazole, $1 \mathrm{~mm}$ EDTA, 8.5 $\mu \mathrm{M}$ leupeptin, and $1 \mathrm{~mm}$ phenylmethyl sulfonylfluoride, $\mathrm{pH}$ 7.2). This homogenate was centrifuged in a Beckman L8M centrifuge at $4000 \times g$ for $15 \mathrm{~min}$ at $4^{\circ} \mathrm{C}$ to remove nuclei and mitochondria. The supernatant was centrifuged at $200,000 \times g$ for $1 \mathrm{hr}$. From the resultant pellet gel samples (in $2 \%$ SDS) were made. Samples of membrane fractions were run on $12 \%$ polyacrylamide minigels (Bio-Rad Mini Protean II). After transfer by electroelution to nitrocellulose membranes, blots were blocked with $5 \%$ milk powder in PBS-T $\left(80 \mathrm{~mm} \mathrm{Na}_{2} \mathrm{PO}_{4}, 20 \mathrm{~mm}\right.$ $\mathrm{NaH}_{2} \mathrm{PO}_{4}, 100 \mathrm{~mm} \mathrm{NaCl}$, and $0.1 \%$ Tween $20, \mathrm{pH} 7.5$ ) for $1 \mathrm{hr}$ and incubated with antibodies against AQP1-5 (either affinity-purified or immune serum). The labeling was visualized with horseradish peroxidase-conjugated secondary antibody (P448; Dako, Glostrup Denmark; diluted 1:3000) using an enhanced chemiluminescence system (Amersham, Buckinghamshire, UK). Controls were made by replacing primary antibody with nonimmune IgG.

Immunocytochemistry. Animals were deeply anesthetized by an intraperitoneal injection of a mixture of midazolam, fentanyl citrate, and fluanisone (3.8, 0.24 , and $7.5 \mathrm{mg} / \mathrm{kg}$ body weight, respectively). Retinas were fixed by transcardiac perfusion $(50 \mathrm{ml} / \mathrm{min}, 20 \mathrm{~min})$ or by immersion in one of the following phosphate-buffered $(1,3$, and 4$)$ or bicarbonatebuffered (2) fixatives: 1, 4\% formaldehyde, $\mathrm{pH} 7.4 ; 2,4 \%$ formaldehyde, $\mathrm{pH}$ 6.0, followed by $4 \%$ formaldehyde, $\mathrm{pH} 10.5$ ("pH shift protocol";
$0.2 \%$ picric acid was added to both solutions); $3,4 \%$ formaldehyde and $0.1 \%$ glutaraldehyde; and 4, $1 \%$ formaldehyde and $2.5 \%$ glutaraldehyde. Light microscopic immunocytochemistry (tissue fixed by fixative 1 , cryoprotected in sucrose, and cut at $15 \mu \mathrm{m}$ on a cryostate) was performed using a method of indirect fluorescence (Veruki and Wässle, 1996). The concentrations of antibodies were LL266, $0.2,0.4$, or $0.8 \mu \mathrm{g} / \mathrm{ml}$; LL127, $0.3 \mu \mathrm{g} / \mathrm{ml}$; LL178, $0.2 \mu \mathrm{g} / \mathrm{ml}$; LL182, 1.0 or $1.6 \mu \mathrm{g} / \mathrm{ml}$; and LL179, 17.4 $\mu \mathrm{g} / \mathrm{ml}$. Antibodies were diluted in $0.01 \mathrm{M}$ phosphate buffer with $3 \%$ normal goat serum, $1 \%$ bovine serum albumin, $0.5 \%$ Triton $\mathrm{X}-100$, and $0.05 \%$ sodium azide, $\mathrm{pH}$ 7.4. The primary antibodies were revealed by a carboxymethylindocyanine-coupled secondary antibody (1:1000; Jackson ImmunoResearch, West Grove, PA). Secondary antibodies were diluted in the same solution as the primary antibodies with the omission of sodium azide. Retinal sections were viewed and photographed with a Leica microscope equipped with epifluorescence optics using filter $\mathrm{m} 2$ (BP 546/14, RKP 580, and LP 580).

For electron microscopic immunocytochemistry, small blocks of the eyecup and optic nerve were subjected to freeze substitution (Schwarz and Humbel, 1989; van Lookeren Campagne et al., 1991) as described by Hjelle et al. (1994). In brief, the specimens were cryoprotected by immersion in graded concentrations of glycerol $(10,20$, and $30 \%)$ in phosphate buffer and plunged into liquid propane $\left(-170^{\circ} \mathrm{C}\right)$ in a cryofixation unit (KF 80; Reichert, Vienna, Austria). The samples were then immersed in $0.5 \%$ uranyl acetate dissolved in anhydrous methanol $\left(-90^{\circ} \mathrm{C}\right)$ in a cryosubstitution unit (AFS, Reichert). The temperature was raised in steps of $4^{\circ} \mathrm{C} / \mathrm{hr}$ to $-45^{\circ} \mathrm{C}$. Samples were washed with anhydrous methanol and infiltrated with Lowicryl $\mathrm{HM} 20$ resin at $-45^{\circ} \mathrm{C}$ with a progressive increase in the ratio of resin to methanol. Polymerization was performed with UV light $(360 \mathrm{~nm})$ for $48 \mathrm{hr}$.

Ultrathin sections were cut with a Reichert ultramicrotome, mounted on nickel grids or gold coated grids, and processed for immunogold cytochemistry as described by Matsubara et al. (1996). Briefly, the sections were treated with a saturated solution of $\mathrm{NaOH}$ in absolute ethanol $(2-3 \mathrm{sec})$, rinsed in phosphate buffer, and incubated sequentially in the following solutions (at room temperature): (1) $0.1 \%$ sodium borohydride and $50 \mathrm{~mm}$ glycine in Tris buffer $(5 \mathrm{mM})$ containing 0.01 or $0.1 \%$ Triton X-100 and 50 or $100 \mathrm{~mm} \mathrm{NaCl}$ (TBNT; $10 \mathrm{~min}$ ); (2) $0.5 \%$ milk powder or $2 \%$ human serum albumin in TBNT (10 min); (3) primary antibody (anti-AQP1, $1.6 \mu \mathrm{g} / \mathrm{ml}$; anti-AQP4, 1.0 or $1.6 \mu \mathrm{g} / \mathrm{ml}$ ) diluted in the solution used in the preceding step ( $2 \mathrm{hr})$; (4) same solution as in 2 (10 $\mathrm{min})$; and (5) gold-conjugated secondary antibody $(15 \mathrm{~nm}$ particles) or Fab fragments $(10 \mathrm{~nm})$, diluted 1:20 in TBNT containing milk powder or human serum albumin and polyethylene glycol $(0.5$ $\mathrm{mg} / \mathrm{ml}, 2 \mathrm{hr}$ ). Finally, the sections were counterstained and examined in a Philips CM10 transmission electron microscope. Controls included preincubating LL182 with excess immunizing peptide $(3.6 \mu \mathrm{g} / \mathrm{ml})$ or a heterologous peptide (PKC- $\gamma)$, or substituting rabbit nonimmune $\operatorname{IgG}(1$ $\mu \mathrm{g} / \mathrm{ml})$ for LL182.

Quantification and statistical analysis. Material immersion-fixed with fixative 3 was used for quantification and statistical analysis. The immunoincubation was performed with anti-AQP4 (LL182AP, $1 \mu \mathrm{g} / \mathrm{ml}$ ) followed by conjugated Fab $(10 \mathrm{~nm})$.

Digital images were acquired with a commercially available image analysis program (analySIS; Soft Imaging Systems Gmbh, Münster, Germany). The program had been modified for acquisition of high-resolution digital images (Haug et al., 1996) and semiautomatic evaluation of immunogold-labeled cellular volumes (Haug et al., 1994; Laake et al., 1995) and surfaces (membranes). For the present purpose, images of membrane segments were recorded at a nominal magnification of $34,000 \times$ in $1280 \times 1024$ (8-bit) images. Each image represented a $1.55 \times$ $1.24 \mu \mathrm{m}$ rectangle, and each pixel represented a $1.2 \times 1.2 \mathrm{~nm}$ square at the level of the specimen.

To avoid the effect of inadvertent differences in general labeling intensity, statistical comparisons were made between membrane domains sampled from one section (code 60,526-s5; 289 images). This section was representative of the $>100$ sections that were investigated (obtained from a total of 15 animals). All membrane segments that could be identified as belonging to vitreal end feet of Müller cells (electron-dense processes) or astrocytes (electron-lucent processes) were imaged; other types of membrane compartments were selected at random. Membrane segments of interest were drawn in the overlay and assigned a type label. Gold particles in the neighborhood of each membrane curve were detected semiautomatically, and the distance between the center of gravity 
of each particle and its membrane curve was calculated by the program. All images, with associated curves, particles, and measurements, were saved to allow later verification and correction.

Further analyses were done partly in analySIS and partly in SPSS. Histograms of the distribution of particles along an axis perpendicular to the membrane were prepared and used to visually discriminate membrane-associated labeling from "background." The corresponding distance (see Fig. 7 legend) was used to exclude non-membraneassociated particles in the following automated calculation of the number of particles per unit length of membrane (linear particle density). For membrane types with low labeling density, short segments will frequently show zero or very low particle density. To reduce the variability (at the cost of a reduced $n$ ) the original membrane segments, with associated particles, were concatenated to segments with a minimum length of 10 $\mu \mathrm{m}$. Subsequently, the means of particle densities were compared between the groups, using the SPSS ANOVA with Student-NewmanKeuls post hoc test.

Plasmids and probe synthesis. The AQP4 cDNA (sequence according to Jung et al., 1994) was contained in the EcoRI site of the pBluescript vector and linearized with PVU I. To synthesize cRNA probes for in situ hybridization assays, runoff transcripts were generated in the presence of digoxigenin-labeled UTP using the T3/T7 RNA polymerase and purified as described by the manufacturer (digoxigenin RNA labeling kit; Boehringer Mannheim) (for details, see Torp et al., 1997).

In situ hybridization. Cryostat sections $(15 \mu \mathrm{m})$ obtained from retina (immersion fixed with $4 \%$ formaldehyde and cryoprotected) or the optic nerve (sections fixed on the slides with $4 \%$ formaldehyde) were treated with ethanol, rehydrated, rinsed in $2 \times \mathrm{SSC}$, and pretreated with proteinase $\mathrm{K}(10 \mu \mathrm{g} / \mathrm{ml})$. The sections were then subjected to a digoxigeninbased labeling procedure (Torp et al., 1997). Briefly, the sections were acetylated and incubated in a hybridization solution containing $50 \%$ formamide, $0.3 \mathrm{M} \mathrm{NaCl}$, and 10-15 ng of digoxigenin-labeled RNA probe $\left(55^{\circ} \mathrm{C}, 16-18 \mathrm{hr}\right)$. After hybridization the sections were immersed sequentially in $2 \times \mathrm{SSC}$ (room temperature, $45 \mathrm{~min}$ ), $2 \times \mathrm{SSC}$ containing $50 \%$ formamide $\left(55^{\circ} \mathrm{C}, 30 \mathrm{~min}\right)$, and $2 \times \mathrm{SSC}$ (room temperature, two times for $10 \mathrm{~min}$ each). Unhybridized RNA was removed by RNase A. Digoxigenin was immunodetected using antibodies labeled with alkaline phosphatase (Boehringer Mannheim). Sense probes were used as a control.

\section{RESULTS}

\section{Immunoblot analysis}

Antibodies to AQP4 or AQP1 labeled a major band of 29-30 or $28 \mathrm{kDa}$, respectively, as well as bands corresponding to higher molecular weights (Fig. $1 A$ ). In previous studies the bands of high molecular weight have been interpreted to represent incompletely insolubilized oligomers (Nielsen et al., 1993a; Terris et al., 1995). The patterns of labeling are consistent with those obtained in previous reports (Denker et al., 1988; Terris et al., 1995) and similar to the immunoblot patterns in cerebellum (Nielsen et al., 1997a) and anterior eye (Nielsen et al., 1993a), structures known to contain high amounts of AQP4 and AQP1, respectively.

\section{Cellular distribution of AQP4 and AQP4 mRNA in the retina}

The immunofluorescence labeling for AQP4 extended from the inner to the outer limiting membranes (Figs. $2 A, 3 B, C$ ) and was identical in all animals $(n=5)$. Particularly strong labeling occurred along blood vessels (Figs. $2 A, 3 A, B$ ), at the vitreal surface (Figs. $2 A, 3 B$ ), and in the outer plexiform layer (Fig. $2 A$, $3 B, C)$. The labeling at the latter site appeared as a delicate meshwork when viewed in oblique sections (Fig. $3 A$ ).

The following observations indicated that the stained profiles belonged to Müller cells and astrocytes. First, in situ hybridization analyses with riboprobes to AQP4 mRNA revealed distinct labeling in the inner nuclear layer, corresponding to the location of the Müller cell perikarya, and somewhat weaker labeling close to the inner limiting membrane, corresponding to the location of

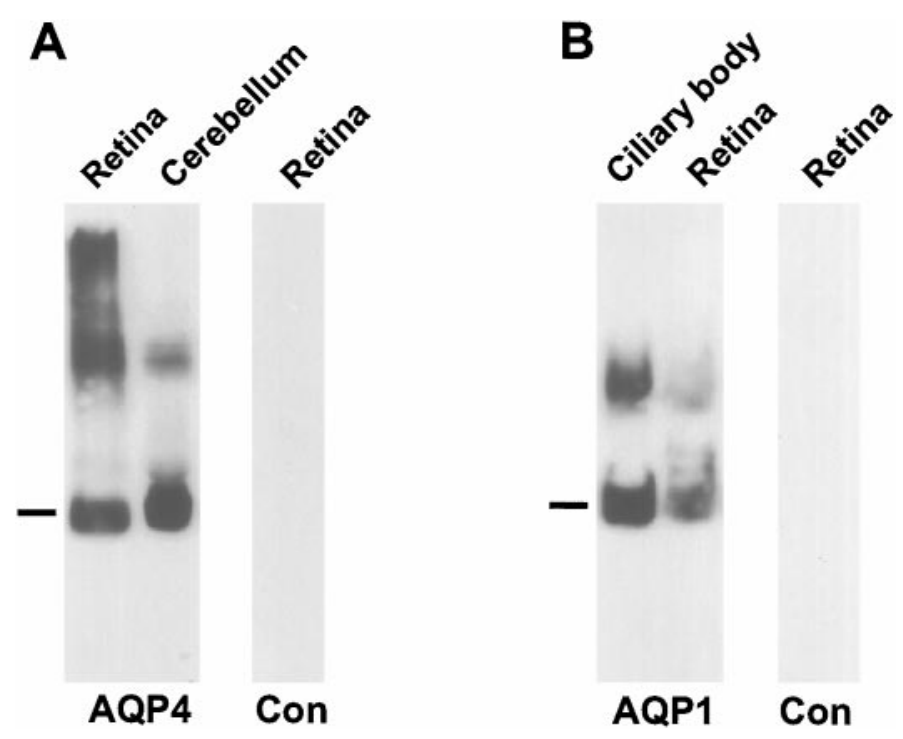

Figure 1. Immunoblots of membrane fractions from rat retina, ciliary body, and cerebellum. In $A$ the blot is probed with affinity-purified antibodies to AQP4 (LL182). A predominant $\sim 30 \mathrm{kDa}$ band (indicated by the bar) is seen in membrane fractions from both cerebellum and retina. The additional 32-34 kDa band corresponds to a splice variant (Lu et al., 1996). Higher molecular weight bands presumably represent oligomeric AQP4 (Nielsen et al., 1997a). In $B$ the blot is probed with affinity-purified antibody to AQP1 (LL266). Bar, $28 \mathrm{kDa}$. Controls (Con) are probed with nonimmune $\mathrm{IgG}$.

the retinal astrocytes (Fig. $2 B$ ). Second, by use of immunogold labeling it could be resolved that the strong AQP4 immunoreactivity along blood vessels and the vitreal surface resided in perivascular (Fig. 4B,D,F) and vitreal (Fig. 4A,F) end feet, respectively, whereas the labeling in the outer plexiform layer was concentrated in the thin glial processes between the photoreceptor terminals (Fig. $5 E$ ). The labeling in the inner plexiform layer (Fig. $3 B, C$ ) can also be attributed to Müller cell processes, because these were the only elements that were distinctly labeled in this region at the ultrastructural level (Fig. 5D).

The vitreal end feet of astrocytes, identified by their low electron density, were found to be almost as strongly immunoreactive as the more electron-dense end feet of Müller cells (see Figs. $4 A, 7 B$ ). Labeling was also associated with astrocytic processes surrounding vessels in the nerve fiber layer (Fig. $4 F$ ).

Gold particles may end up as far as 20-30 nm from their respective epitopes (Matsubara et al., 1996), reflecting the size of the interposed immunoglobulins. This may lead to problems of interpretation at sites of close apposition between glial and neuronal membranes (Fig. 5E). However, because no particles were found over neuronal membranes where they abut on other neuronal membranes (Fig. 5D) or on an enlarged extracellular space (Fig. 6B), it is likely that the immunogold labeling for AQP4 depends entirely on glial epitopes. This is supported by the quantitative analysis of the gold particle distribution, which showed a distinct peak coinciding with the glial plasma membrane (Fig. 7A). Furthermore, there was no detectable in situ hybridization signal over neuronal cells. Pigment epithelial cells similarly appeared to be devoid of AQP4 (Figs. 3C, 6C) as well as its respective mRNA (data not shown).

Endothelial cells showed very few immunogold particles in material fixed with glutaraldehyde, but some labeling was seen over caveola-like invaginations in these cells after fixation by 

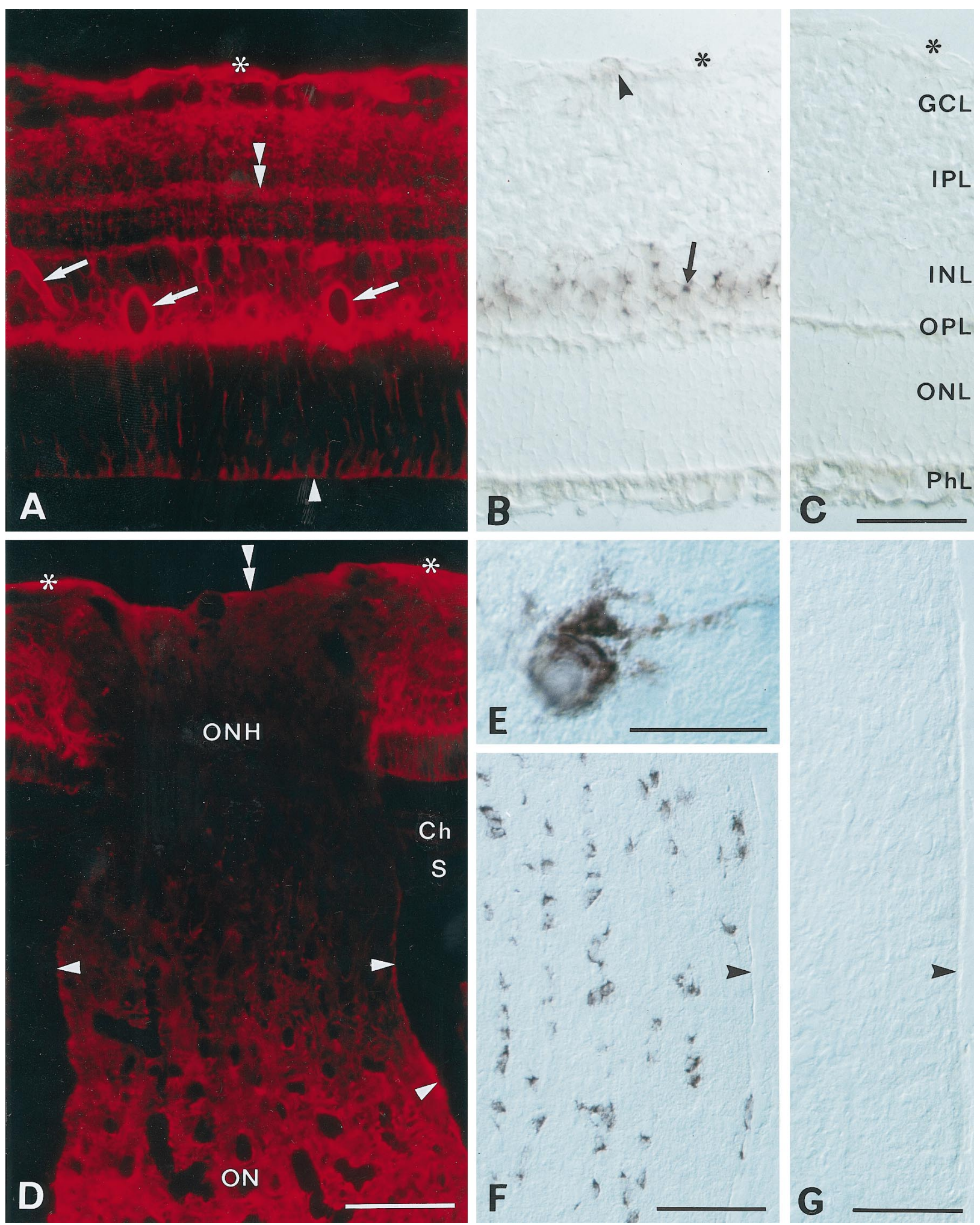

Figure 2. Distribution of AQP4 immunoreactivity $(A, D)$ and AQP4 mRNA $(B, E, F)$ in the retina and optic nerve. $A$, Immunofluorescence of AQP4 in the central retina. Immunolabeling extends from the inner to the outer limiting membrane (asterisk and arrowhead, respectively) and is concentrated along vessels (arrows) and the vitreal surface and in the outer plexiform layer. Note laminar labeling (double arrowhead) in the inner plexiform layer $B$, Section corresponding to that in $A$, incubated with a digoxigenin-labeled probe to AQP4 mRNA. Note strong staining in the inner nuclear layer (arrow) and scattered and weaker staining in the nerve fiber layer (arrowhead). Interference optics. Asterisk, Inner limiting membrane. $C$, Sense control. $G C L$, Ganglion cell layer; $I P L$, inner plexiform layer; $I N L$, inner nuclear layer; $O P L$, outer plexiform layer; $O N L$, outer nuclear layer; $P h L$, photoreceptor layer. $D$, The optic nerve head $(O N H$; longitudinal section) shows weak labeling compared with the retina and the optic nerve $(O N)$. The choroid $(C h)$ and sclera $(S)$ are immunonegative. Asterisks and double arrowhead, Vitreal surface of retina and optic nerve head, respectively; arrowheads, pial surface of optic nerve. $E$, $F$, High-magnification $(E)$ and low-magnification $(F)$ micrograph of AQP4 mRNA containing cells in the optic nerve. Longitudinal section, interference optics. Arrowhead, Pial surface of nerve. $G$, Sense control. Scale bars: $A-C, 50 \mu \mathrm{m} ; D, F, G, 100 \mu \mathrm{m} ; E, 25 \mu \mathrm{m}$. 

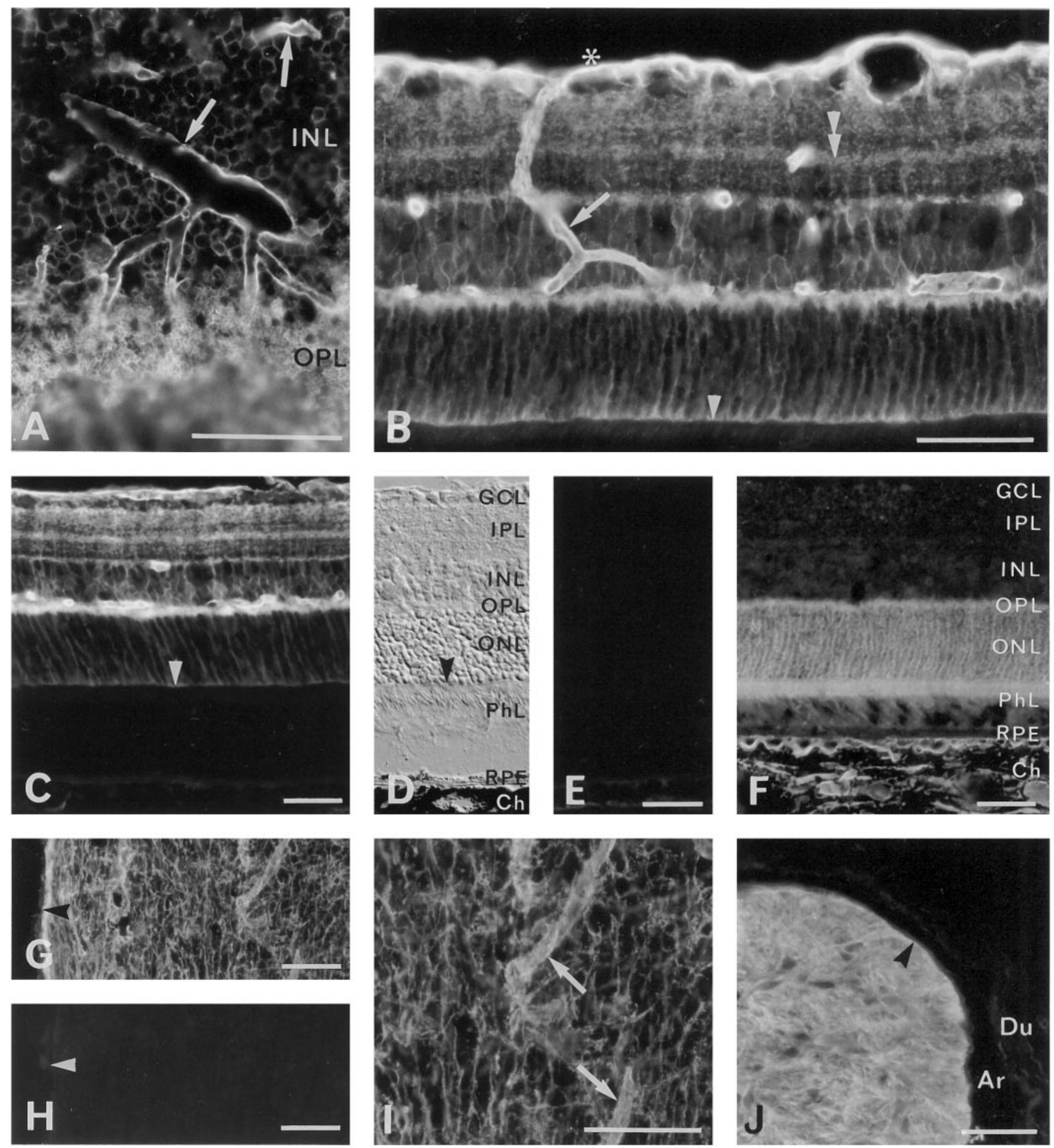

Figure 3. Immunofluorescence of aquaporins in the retina and optic nerve. $A$, AQP4 immunoreactivity in oblique section of the central retina. Note strong labeling around vessels (arrows) and in a meshwork of processes (of Müller cells; see Fig. $5 E$ ) in the outer plexiform layer. $B$, Perivascular labeling for AQP4 (arrow) can be followed from the vitreal surface (asterisk) to the outer plexiform layer. Also see laminar labeling (double arrowhead) in the inner plexiform layer and moderate immunoreactivity at the outer limiting membrane (arrowhead). C, There is no detectable AQP4 immunoreactivity external to the outer limiting membrane (arrowhead), i.e., in the photoreceptors, pigment epithelial cells, and choroid. See $D$ for orientation. $D$, Interference optics, same section as in C. Arrowhead, Outer limiting membrane. $R P E$, Retinal pigment epithelium; $C h$, choroid; other abbreviations as in Figure $2 C$. $E$, Neighboring section to that in $C$ and $D$. No labeling remains after omission of primary antibody, except for a weak autofluorescence in the choroid. $F$, The AQP1 immunoreactivity is concentrated in the outer part of the retina, corresponding to the localization of the photoreceptors, and in the choroid. $G, H, \mathrm{AQP} 4$ immunoreactivity in a longitudinally cut optic nerve ( $G$; close to the optic chiasm) with corresponding omission control $(H)$. Arrowheads, Pial surface. $I$, Detail of $G$ at higher magnification. Note increased labeling around vessels (arrows). $J$, AQP4 immunoreactivity in an obliquely cut optic nerve (postlaminar part). The meninges are unlabeled. Arrowhead, Pial surface of nerve. Ar, Arachnoid; Du, dura mater. The antibody used in $J$ was LL179AP. Scale bars, $50 \mu \mathrm{m}$. 

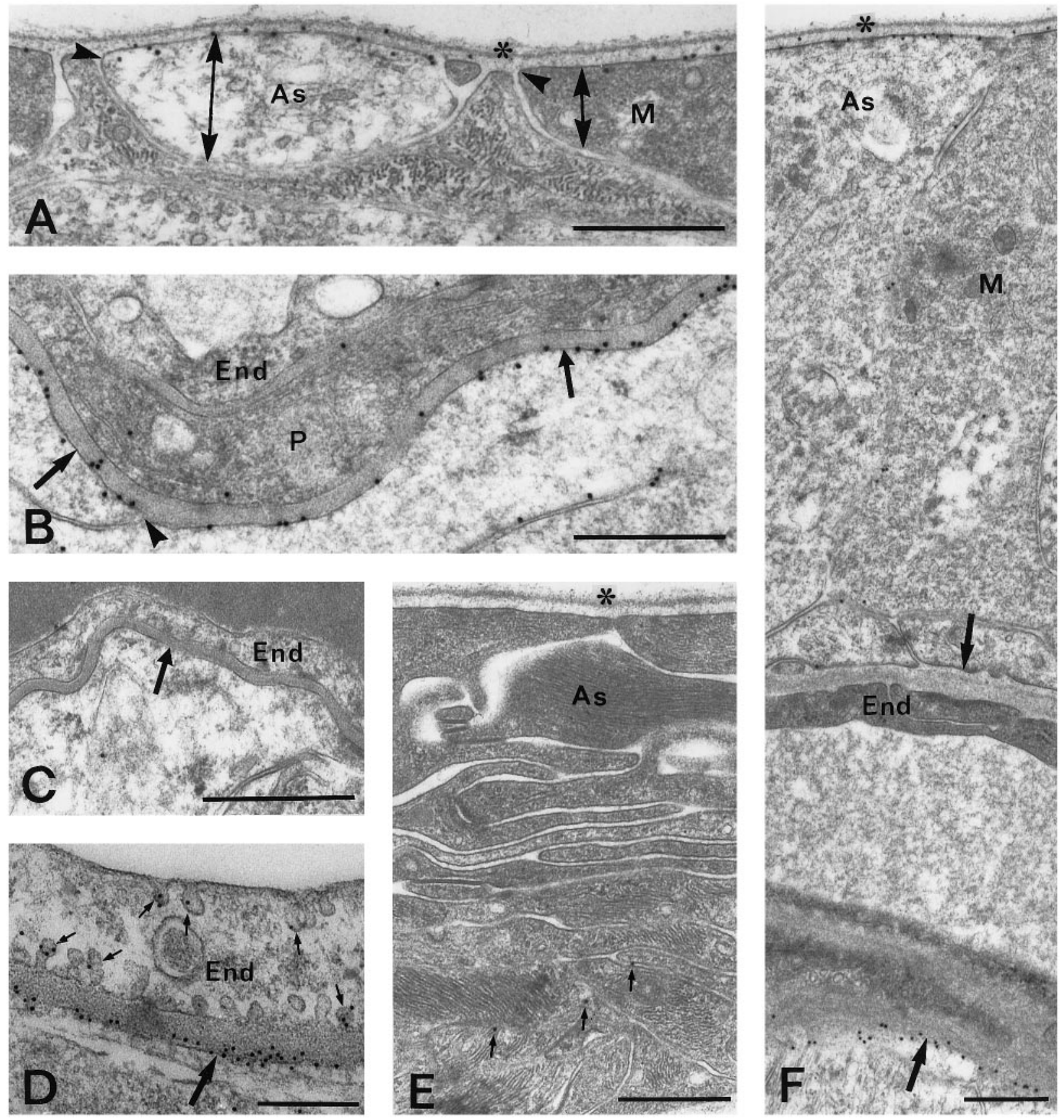

Figure 4. Electron micrographs showing AQP4 immunoreactivity in the retina. A, AQP4 is strongly expressed at the vitreal membranes of astrocytic $(A s)$ and Müller cell $(M)$ end feet but is absent from or weakly expressed in the lateral membranes of these processes. The different membrane domains are indicated by double arrows; the sites of membrane reflection by are indicated by arrowheads. Asterisk, Vitreal surface. $B$, Numerous gold particles signaling AQP4 are found in Müller cell membranes (arrows) facing a capillary in the outer plexiform layer. The labeling is reduced where the membrane turns away from the basal lamina (arrow). End, Endothelial cell; $P$, pericyte. $C$, Preadsorption control. $D$, Same as $B$, but higher sensitivity is obtained by use of the $\mathrm{pH}$ shift fixation protocol and $10 \mathrm{~nm}$ gold particles. Some gold particles are associated with caveola-like invaginations (small arrows) of the endothelial cell. E, Sparse labeling (small arrows mark gold particles) of astrocytic processes (As) in the optic nerve head. Asterisk, Vitreal surface. $F$, Asymmetric distribution of AQP4 around a blood vessel in the nerve fiber layer of the retina. Arrows, Perivascular membranes of glial end feet. Abbreviations as in $A$ and $B$. The glial end feet at the inner (vitreal) aspect of the vessel are immunonegative, whereas the end feet at the outer aspect are strongly immunopositive. Scale bars, $A-C, E, F, 0.5 \mu \mathrm{m} ; D, 0.25 \mu \mathrm{m}$.

formaldehyde alone (Fig. 4D). The latter protocol led to a general increase in the immunolabeling intensity (e.g., Fig. 4, compare the perivascular immunogold signal in $B$ with that in $D$ ) and did not change the ratio between glial and endothelial cell labeling.

\section{Differentiated distribution of AQP4 immunolabeling along Müller cell and astrocyte plasma membranes}

Gold particles signaling AQP4 were highly concentrated along those membrane domains that face the vitreous body or blood 

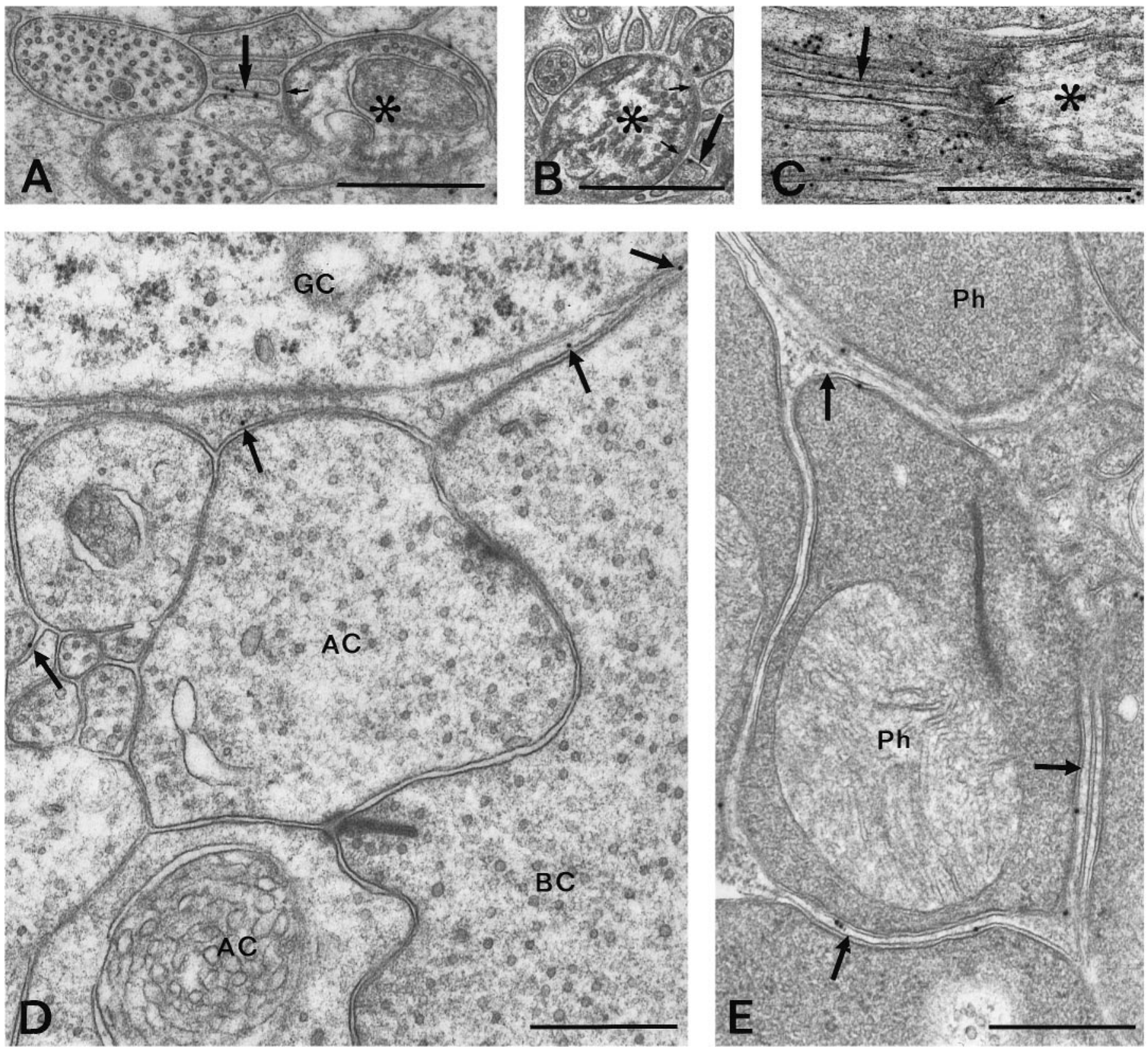

Figure 5. Electron micrographs showing AQP4 immunoreactivity in the nerve fiber layer $(A-C)$ and in the inner $(D)$ and outer $(E)$ plexiform layers. Gold particles occur in glial processes (arrows) surrounding node-like membrane specializations of nonmyelinated ganglion cell axons (asterisks). The axons at these regions display an electron-dense subaxolemmal undercoating (small arrows). The $\mathrm{pH}$ shift fixation protocol was used for the material shown in $C$. $D, E$, Scattered particles (arrows) are associated with thin glial processes separating unlabeled neuronal elements. $A C$, Amacrine cell; $B C$, bipolar cell; $G C$, ganglion cell; $P h$, photoreceptor terminal. Scale bars, $0.5 \mu \mathrm{m}$.

vessels (Fig. 4A,B,D,F). The labeling dropped abruptly (by $\sim 90 \%$ ) where the membranes turned away from the respective basal membranes (Fig. $4 A, B$ ) to reach the low linear density typical of non-end feet membranes (Figs. 5D,E, 7B). Vitreal end feet derived from astrocytes exhibited the same labeling pattern as those derived from Müller cells (Figs. 4A, 7B). The non-end feet membranes of Müller cells revealed no radial gradient in labeling intensity (Fig. $7 B$ ). However, the microvilli were associated with lower particle densities than the rest of the Müller cell plasma membrane (Figs. $6 A, 7 B$ ) and failed to show detectable AQP4 immunofluorescence (Figs. 2A, 3B, C).
The perivascular end feet were equally strongly labeled along the entire circumference of the retinal vessels. The only exceptions to this were noted close to the inner limiting membrane (i.e., in the nerve fiber layer), where end feet contacting the vitreal aspect of the vessels were clearly less strongly labeled than those contacting the outer aspect (Fig. $4 F$ ). The same labeling pattern was obtained in all animals subjected to immunogold analysis.

\section{AQP4 in the nerve fiber layer and optic nerve}

The posterior part of the optic nerve exhibited rows of cells that were strongly labeled for AQP4 mRNA (Fig. 2E,F) and also 

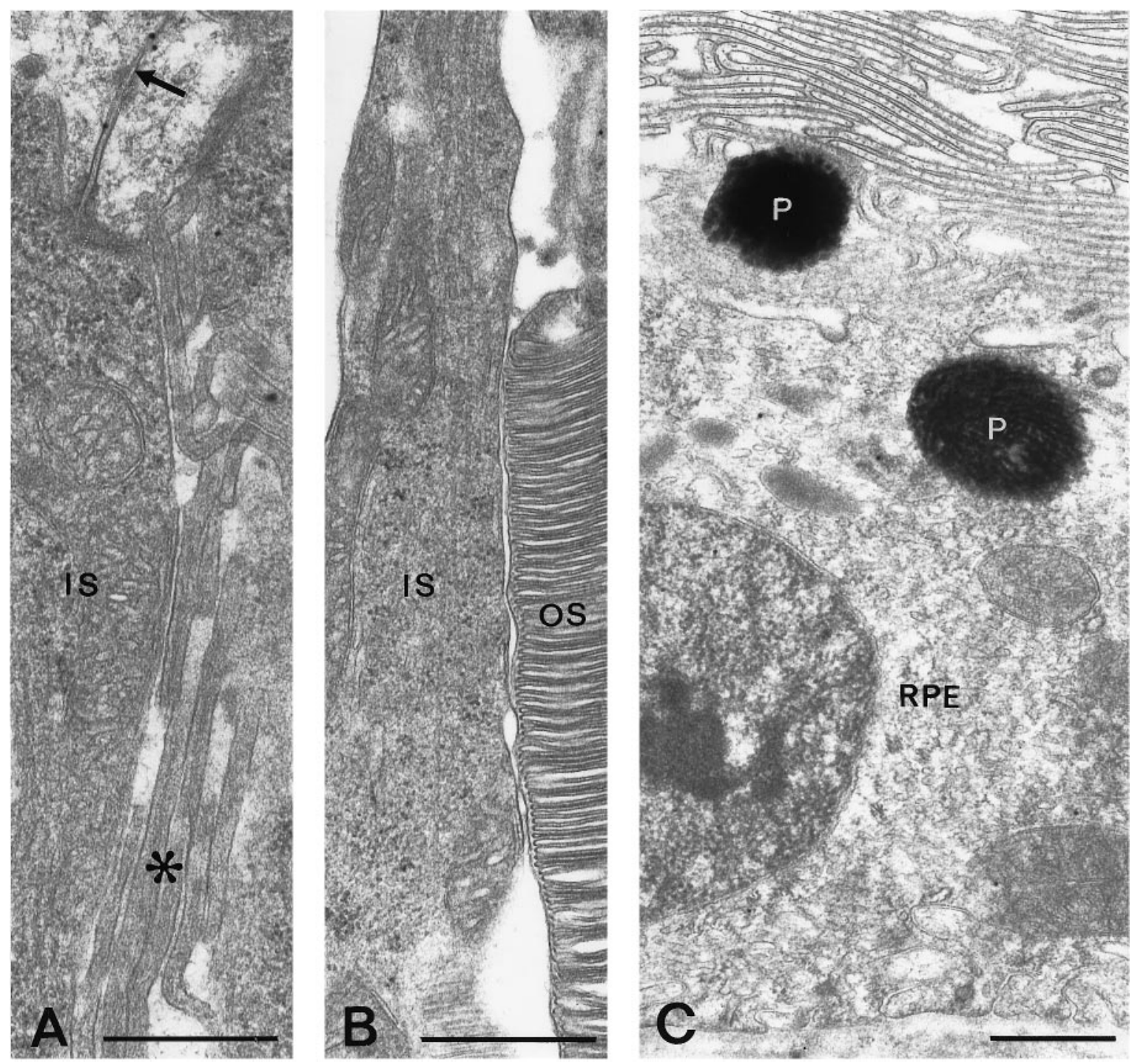

Figure 6. AQP4 immunogold labeling in the outer retina. $A$, Gold particles are found along Müller cell membranes (arrow) on the internal side of the outer limiting membrane but rarely occur in the microvilli (asterisk). $B, C$, Inner and outer segments of photoreceptors (IS, OS, respectively) and retinal pigment epithelial cells $(R P E)$ are immunonegative. $P$, Pigment granules. Scale bars, $0.5 \mu \mathrm{m}$.

contained a dense network of AQP4-immunopositive processes (Fig. 3G,I,J). Using the electron microscope, the labeled cells were identified as fibrous astrocytes (Fig. 8). Particularly strong AQP4 labeling occurred in astrocytic membranes contacting blood vessels (Fig. $3 G, I$ ) or pia (Figs. $3 G, 8 E$ ), whereas astrocytic membranes facing the axolemma at nodes of Ranvier were nearly devoid of labeling (Fig. $8 A-C$ ). The remaining astrocytic membrane displayed an intermediate labeling intensity (Fig. $8 A-D$ ). Oligodendrocytes were unlabeled (Fig. 8A,D).

The ganglion cell axons in the retinal nerve fiber layer are unmyelinated but display node-like membrane specializations (Hildebrand and Waxman, 1983). Like the true nodes in the optic nerve, these specializations are associated with glial processes that are polarized with respect to their AQP4 immunoreactivity (Fig. 5A-C); i.e., most of the particles were found at membranes oriented away from the node-like specialization.

AQP4 mRNA labeling was absent or weak in most of the optic nerve head (data not shown). Only cells close to large vessels exhibited some staining. In agreement, the optic nerve head showed low AQP4 immunoreactivity (Fig. 2D). There was a sharp reduction in immunolabeling on moving from the retina into the prelaminar part of the optic nerve head, and the staining remained weak through the laminar part. The staining intensity then increased in the postlaminar part to reach the level typical of the rest of the optic nerve. Electron microscopy revealed very weak immunogold labeling of the electron-dense glial processes that are characteristic of the nerve head (Figs. $4 E, 8 F$ ). The few processes that exhibited relatively high particle densities typically had a pale cytoplasmic matrix and occurred in proximity to vessels (Fig. $8 F$ ).

The meninges did not display detectable immunolabeling (Fig. $3 J$ ).

\section{Other aquaporins}

An antibody to another member of the aquaporin family (AQP1) produced a pattern of labeling distinct from that of AQP4 (Fig. $3 F$ ). At low concentrations of AQP1 antibody the immunofluorescence predominated in the choroid and sclera, whereas higher 


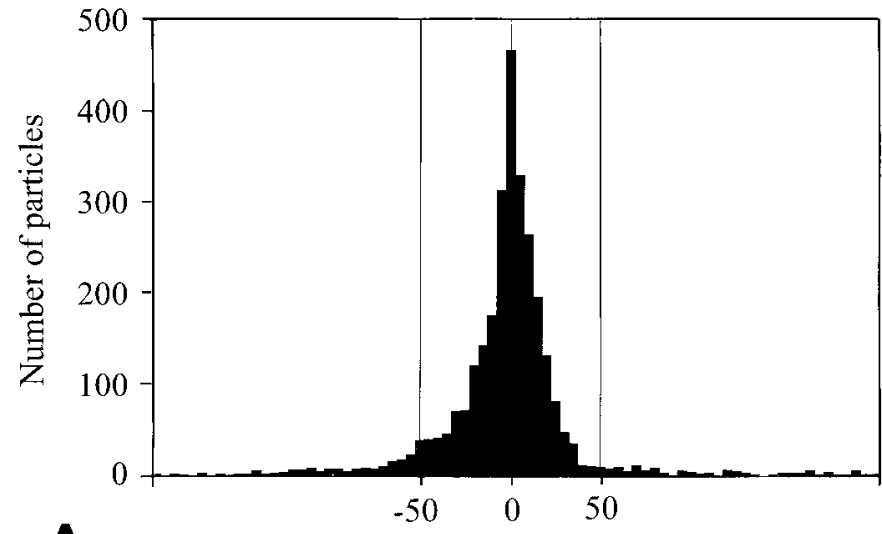

A Distance from midpoint of membrane (nm)

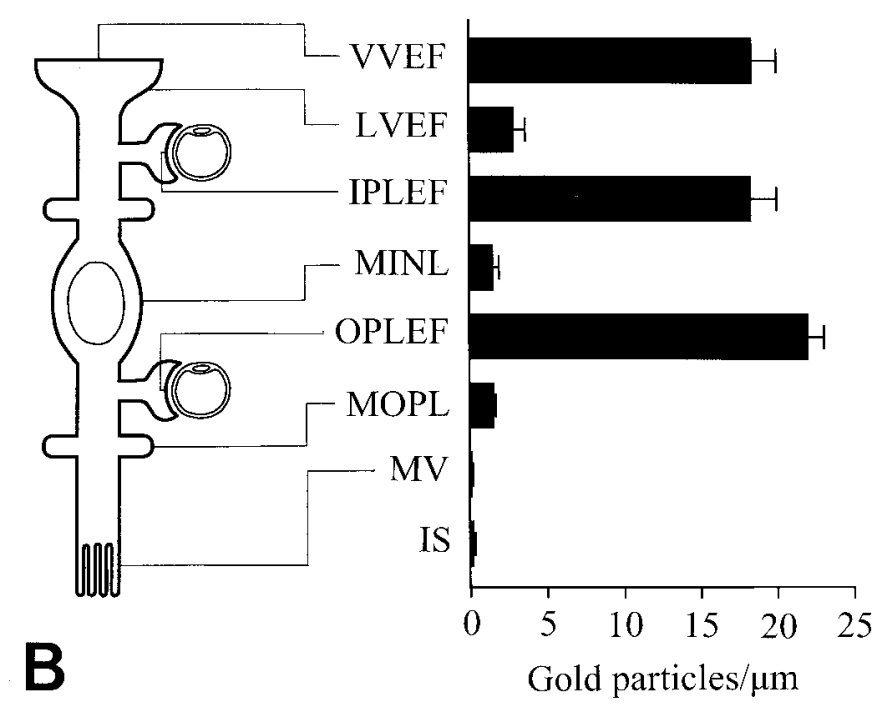

Figure 7. Quantitative analysis of AQP4 immunogold labeling in Müller cells. $A$, Distribution of gold particles along an axis perpendicular to the Müller cell plasma membrane. The ordinate indicates number of gold particles per bin (bin width, $5 \mathrm{~nm}$ ). The data were pooled from all Müller cell membrane domains represented in $B$ (each membrane fragment was 0.4-7 $\mu \mathrm{m}$; the total number of gold particles was $>3000$ ). The peak coincided with the plasma membrane $(0$ corresponds to midpoint of membrane) and the particle density approached background level at $\sim 50$ $\mathrm{nm}$ from the membrane (inside negative). $B$, Diagram showing gold particle densities in different Müller cell membrane domains. Particles were included if they were situated within $50 \mathrm{~nm}$ of the membrane (cf. $A$ ). The location of each domain is indicated at the left. VVEF, Vitreal membranes of vitreal end feet (number of observations, $n=26$ ); $L V E F$, lateral membranes of vitreal end feet $(n=27)$; IPLEF, perivascular end feet in the inner plexiform layer $(n=17)$; $M I N L$, Müller cell membranes in the inner nuclear layer $(n=14) ; O P L E F$, perivascular end feet in the outer plexiform layer $(n=55)$; MOPL, Müller cell processes in the outer plexiform layer $(n=93) ; M V$, Müller cell microvilli $(n=43)$. The photoreceptor inner segments $(I S)$ are included for comparison $(n=42)$. Values are mean number of gold particles per micrometer \pm SEM. The values for the end feet membranes (VVEF, IPLEF, and OPLEF) are significantly different from all other values $(p<0.05$, Student-NewmanKeuls test). The values for microvilli and photoreceptor inner segment membranes were significantly different from $L V E F, M I N L$, and MOPL $(p<0.05$, Student-Newman-Keuls test; for statistical comparison the data from the latter three membrane domains were pooled. Membranes were concatenated to form fragments with a minimum length of $10 \mu \mathrm{m}$ ). Vitreal end feet of astrocytes also displayed a polarized expression of AQP4 (data not shown). Mean numbers of gold particles per micrometer $\pm \operatorname{SEM}(n)$ in the vitreal and lateral membrane domains of astrocytic end feet were $12.8 \pm 1.9(16)$ and $0.6 \pm 0.2(12)$, respectively. concentrations of antibody revealed additional immunostaining in the outer retina, corresponding to the location of the photoreceptors (Fig. $3 F$ ). The weak immunogold labeling obtained by the AQP1 antibody did not allow any definite conclusion as to the subcellular distribution of the particles. Antibodies to AQP2 and AQP3 failed to produce any detectable immunofluorescence in the retina, and antibodies to AQP2, AQP3, and AQP5 gave no signal in immunoblots (data not shown).

\section{Controls}

The substitution of the antisense riboprobe with an equal concentration of a sense probe abolished the labeling of the retina and the optic nerve (Fig. 2C,G). No immunolabeling was observed after omission of the primary antibody (Fig. 3E,H) or after preadsorbing the AQP4 antibody with excess immunizing peptide (Fig. 4C), whereas the labeling was unchanged when a heterologous peptide was used for preadsorption (data not shown). Replacement of the primary antibody with nonimmune $\mathrm{IgG}$ led to a weak and nondifferentiated labeling (data not shown). The labeling pattern obtained with AQP4 antibody LL182AP was reproduced with an antibody directed against a nonoverlapping sequence of the same protein (LL179AP; Fig. 3J). It should be noted that Figures $3 J$ and $2 D$ represent a more anterior part of the optic nerve than Figure $3 G$; thus the weaker labeling in the latter micrograph may reflect the lower density of astrocytes in the posterior compared with the anterior portion of the nerve (Skoff et al., 1986).

The different fixation protocols (perfusion or immersion) led to the same general pattern of labeling (compare Figs. $2 A, 3 B$ ), and the two rat strains produced the same results. However, the sensitivity of the immunogold procedure was enhanced by using smaller gold particles, by reducing the glutaraldehyde contents of the standard fixative, or by substituting the standard fixation with the $\mathrm{pH}$ shift protocol (Figs. $4 D, 5 C, 8 C-E$; also see above).

\section{DISCUSSION}

This study shows that AQP4 is heterogeneously expressed in the retina and optic nerve, at the cellular as well as the subcellular level. Assuming that AQP4 is the predominant mediator of osmotic water flux in these tissues, our findings imply that Müller cells and astrocytes perform a central role in water handling and that they may direct the water flux to specific cellular and extracellular compartments. Obviously the pattern of water flux not only is determined by the precise distribution of aquaporins but also depends on the magnitude and direction of the osmotic driving forces, as will be discussed below.

\section{Activity-dependent ion fluxes and osmotic gradients in the retina}

The retina and optic nerve have been attractive models for analyses of activity-dependent ion fluxes and water redistribution (for review, see Newman, 1996; Ransom and Orkand, 1996). These analyses have provided unequivocal evidence that glial cells contribute to the shuttling of excess $\mathrm{K}^{+}$away from areas of high neuronal activity. The removal of $\mathrm{K}^{+}$by glial cells is mediated by several different mechanisms (for review, see Walz, 1989; Newman, 1995), including $\mathrm{K}^{+}$spatial current (Orkand et al., 1966; Dietzel et al., 1980, 1982, 1989; Gardner-Medwin 1983a,b; Gardner-Medwin and Nicholson, 1983; Coles and Poulain, 1991), passive uptake of $\mathrm{KCl}$ (via cotransport or separate channels; 

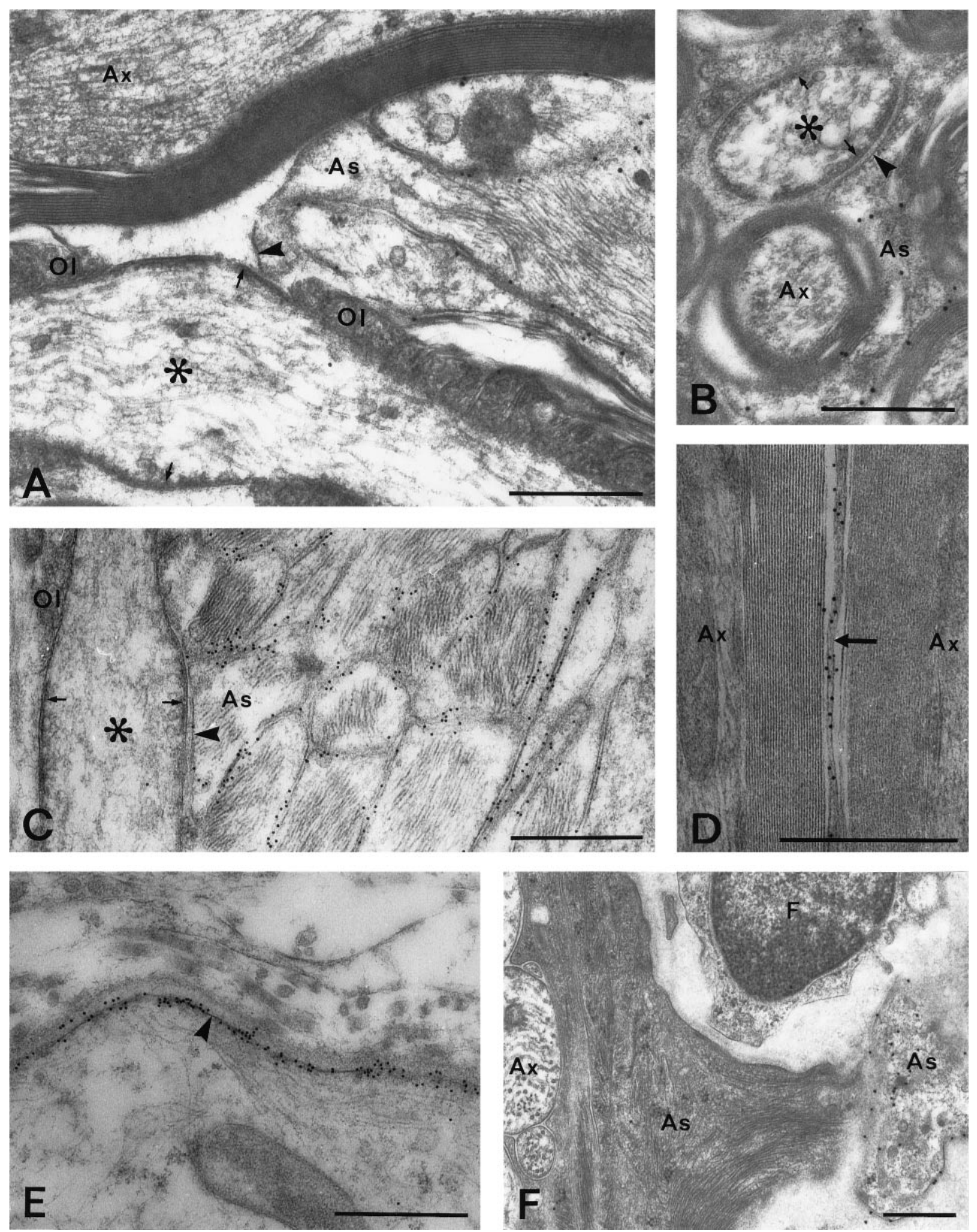

Figure 8. AQP4 immunoreactivity in the posterior part of the optic nerve $(A-E)$ and in the optic nerve head $(F)$. $A, B$, Longitudinal $(A)$ and transverse $(B)$ sections through the nerve. Particles are found in astrocytic processes $(A s)$ in contact with the nodes of Ranvier (asterisks) but are scarce in those membrane domains that are directly apposed to the axonal surface (arrowheads). Note the subaxolemmal electron-dense undercoating (arrows) that is characteristic of nodes. $\mathrm{Ol}$, Loops of oligodendrocytes. $C$, As in $A$, but close to pial surface: $\mathrm{pH}$ shift fixation protocol and $10 \mathrm{~nm}$ gold particles. Numerous gold particles are found along the plasma membranes of glial processes, easily identified by their filaments. $D$, AQP4-immunopositive astrocytic process (arrow) sandwiched between two myelinated axons $(A x), \mathrm{pH}$ shift fixation. $E$, Immunogold labeling of glia limitans $($ arrowhead), $\mathrm{pH}$ shift fixation. $F$, Retinal part of optic nerve head. AQP4 is expressed in a pale astrocytic process that was found to contact a large vessel (outside margin of micrograph). Most of the astrocytic processes in this part of the optic nerve show a dense cytoplasmic matrix and display weak immunoreactivity. As, Astrocytic process; $A x$, unmyelinated axons. Scale bars, $0.5 \mu \mathrm{m}$. 
Kimelberg and Frangakis, 1985; Walz and Hinks, 1985; Ballanyi et al., 1987; Tas et al., 1987; Walz, 1987; Dietzel et al., 1989), and active uptake by $\mathrm{Na}^{+}, \mathrm{K}^{+}$ATPase (Walz and Hertz, 1982; Reichenbach et al., 1986, 1992; Ballanyi et al., 1987; Dietzel et al., 1989).

The $\mathrm{K}^{+}$spatial current in the retina is known to be funneled through the Müller cell end feet, a process referred to as $\mathrm{K}^{+}$ siphoning (Newman et al., 1984). In the avascular amphibian and rabbit retinae it has been estimated that $80-95 \%$ of the total $\mathrm{K}^{+}$ conductance in Müller cells is localized in the vitreal end feet (Newman, 1984, 1985; Brew et al., 1986; Reichenbach et al., 1992). This implies that the vitreous body acts as a sink for the $\mathrm{K}^{+}$ions that are released from active neurons (Karwoski et al., 1989). In species with vascular retinas the perivascular end feet may act as an additional efflux pathway for $\mathrm{K}^{+}$(Paulson and Newman, 1987).

On theoretical grounds it can be predicted that $\mathrm{K}^{+}$removal by $\mathrm{K}^{+}$spatial current and $\mathrm{KCl}$ uptake will tend to reduce the extracellular osmolarity around the active neurons (Dietzel et al., 1989). Thus, activity leads to an osmotic gradient that favors water flux from the extracellular to the intracellular space. In agreement, studies in the synaptic layers of the retina (Orkand et al., 1984; Li et al., 1994a), optic nerve (Connors et al., 1982; Ransom et al., 1985), cerebral cortex (Dietzel et al., 1980, 1982), and spinal cord (Syková, 1987; Svoboda and Syková, 1991) have revealed that neuronal activity leads to a delayed reduction of the extracellular volume. Glial cells seem to be more prone to swelling than neurons under enhanced neuronal activity and other conditions that lead to osmotic perturbations (Wasterlain and Torack, 1975; Söderfeldt et al., 1981; Kimelberg and Ransom, 1986; Sztriha, 1986; Olson et al., 1990; Nagelhus et al., 1993), indicating that the excess water may be directed primarily into glial cells. This can be easily explained if the glial cell membranes are equipped with water channels that facilitate osmotic water flux.

\section{Aquaporin-4 in Müller cells}

The present data indeed suggest that Müller cells express a water channel, and that its membrane distribution may be tuned to the $\mathrm{K}^{+}$conductance. Notably, the strong enrichment of AQP4 immunoreactivity at vitreal and perivascular end feet matches the preferential localization of $\mathrm{K}^{+}$channels at these sites (Newman, 1987; Reichenbach et al., 1992) and indicates that AQP4 may be in an ideal position to mediate the water flux associated with $\mathrm{K}^{+}$siphoning in the retina. The preferential and polarized expression of AQP4 in Müller cells and astrocytes would serve to direct the water flux into the glial compartment and further into the vitreous body or vascular space. This flux will be reversed when the neuronal activity abates. The absence of detectable AQP4 immunoreactivity in neuronal membranes suggests that these have a very low water permeability (although photoreceptors may contain some AQP1; see below), which should alleviate or delay activitydependent volume changes of neuronal compartments.

One interpretation of the weak AQP4 immunolabeling in glial membranes contacting the vitreal aspect of the inner retinal vessels is that the vitreous body is the preferred route of water exit. The small AQP4 pool in the endothelial cells may be involved in the transcapillary water transfer.

In most species the Müller cell microvilli show a lower $\mathrm{K}^{+}$ conductance than the end feet (Newman, 1987), and we have presently demonstrated that they fail to express detectable amounts of AQP4. The microvilli of guinea pigs are also devoid of orthogonal arrays of intramembranaceous particles (OAPs) (Gotow and Hashimoto, 1989), which according to recent data may represent clustered AQP4 (Yang et al., 1996; Verbavatz et al., 1997). Taken together these data suggest that the Müller cells of rodents do not use their apical membrane domain as an efflux route for water, although the properties of the microvilli may vary across species (Newman, 1987). The absence of AQP4 at the apical Müller cell membrane should help counteract inappropriate volume changes of the subretinal space.

One might ask whether the water flux in the retina could depend on several different aquaporins, as in the kidney. Of all the aquaporins for which antibodies are currently available (AQP1-5), only AQP4 and AQP1 were detected in the retina. This is in agreement with the distribution of the respective mRNAs (Patil et al., 1997). Although immunocytochemistry does not permit an assessment of their relative concentrations, the fact that the AQP1 immunofluorescence signal in the retina was much weaker than that in the choroid and sclera suggests a rather low retinal expression of this protein.

Aquaporins are the only known class of proteins that facilitates osmotic water flux. However, water movement through membranes may also occur by cotransport with organic or inorganic solutes (Zeuthen, 1996). Because the pigment epithelial cells do not seem to contain any of the known aquaporins, one may speculate that the obligatory water flux through these cells (which are linked by tight junctions) occurs primarily by cotransport, e.g., with $\mathrm{Na}^{+}, \mathrm{K}^{+}$, and $\mathrm{Cl}^{-}$(see Li et al., 1994b).

\section{Aquaporin-4 in the optic nerve}

Glial $\mathrm{K}^{+}$buffering is required not only in neuropil but also in white matter. Perinodal astrocytic processes have been implicated in the removal of the $\mathrm{K}^{+}$ions that are released at the nodes of Ranvier during action potential propagation (Ransom et al., 1985). The excess $\mathrm{K}^{+}$may be funneled to the subarachnoidal space or to the bloodstream, in parallel to the situation in neuropil, because end feet of optic nerve astrocytes display high potassium conductance (Newman, 1986). The distribution of AQP4 in the optic nerve is consistent with our hypothesis that this protein plays an auxiliary role in $\mathrm{K}^{+}$spatial buffering. Thus AQP4 was expressed at the perinodal processes and in subpial and perivascular end feet, with the higher concentration in the end feet. In the perinodal processes AQP4 was expressed preferentially in the membrane domains that face away from the nodal membrane. This arrangement would facilitate water influx from the extracellular space at a distance from the node and would serve to protect against volume fluctuations in the perinodal extracellular space.

The low expression of AQP4 (and of OAPs; see Bäuerle and Wolburg, 1993) in the optic nerve head correlates with the absence of myelin in this part of the nerve. The $\mathrm{K}^{+}$efflux in unmyelinated nerves is spread out along the axons and would not require as efficient buffering mechanisms as in myelinated nerves, in which the $\mathrm{K}^{+}$efflux is concentrated to the nodes. In agreement, myelin-deficient rats fail to show the polarized distribution of OAPs typical of fibrous astrocytes in normal rats (Rohlmann et al., 1992). 


\section{Conclusion}

Glial cells help maintain the function of neuronal cells by removing transmitters and providing energy substrates and transmitter precursors. Furthermore, by linking the neurons to the vascular and liquor compartments, they are of importance for the handling of organic osmolytes and water under osmotic stress and for the siphoning of $\mathrm{K}^{+}$under high neuronal activity. The present findings suggest that glial cells may serve to direct water flux in neural tissue by targeting the AQP4 water channel to discrete membrane domains.

\section{REFERENCES}

Agre P, Brown D, Nielsen S (1995) Aquaporin water channels: unanswered questions and unresolved controversies. Curr Opin Cell Biol 7:472-483.

Amédée T, Robert A, Coles JA (1997) Potassium homeostasis and glial energy metabolism. Glia 21:46-55.

Andrew RD, MacVicar BA (1994) Imaging cell volume changes and neuronal excitation in the hippocampal slice. Neuroscience 62:371-383.

Ballanyi K, Grafe P, Bruggencate GT (1987) Ion activities and potassium uptake mechanisms of glial cells in guinea-pig olfactory cortex slices. J Physiol (Lond) 382:159-174.

Brew H, Gray PTA, Mobbs P, Attwell D (1986) Endfeet of retinal glial cells have higher densities of ion channels that mediate $\mathrm{K}^{+}$buffering. Nature 324:466-468.

Bäuerle C, Wolburg H (1993) Astrocytes in the nonmyelinated lamina cribrosa of the rat are less polarized than in the optic nerve proper: a freeze-fracture study. Glia 9:238-241.

Chebabo SR, Hester MA, Aitken PG, Somjen GG (1995) Hypotonic exposure enhances synaptic transmission and triggers spreading depression in rat hippocampal tissue slices. Brain Res 695:203-216.

Chrispeels MJ, Agre P (1994) Aquaporins: water channel proteins of plant and animal cells. Trends Biochem Sci 19:421-425.

Coles JA (1986) Homeostasis of extracellular fluid in retinas of invertebrates and vertebrates. Prog Sens Physiol 6:109-138.

Coles JA, Poulain DA (1991) Extracellular $\mathrm{K}^{+}$in the supraoptic nucleus of the rat during reflex bursting activity by oxytocin neurones. J Physiol (Lond) 439:383-409.

Coles JA, Orkand RK, Yamate CL, Tsacopoulos M (1986) Free concentrations of $\mathrm{Na}, \mathrm{K}$, and $\mathrm{Cl}$ in the retina of the honeybee drone: stimulusinduced redistribution and homeostasis. Ann NY Acad Sci 481:303-317.

Connors BW, Ransom BR, Kunis DM, Gutnick MJ (1982) Activitydependent $\mathrm{K}^{+}$accumulation in the developing rat optic nerve. Science 216:1341-1343.

Deitmer JW, Rose CR (1996) $\mathrm{pH}$ regulation and proton signalling by glial cells. Prog Neurobiol 48:73-103.

Denker BM, Smith BL, Kuhajda FP, Agre P (1988) Identification, purification, and partial characterization of a novel $M_{\mathrm{r}} 28,000$ integral membrane protein from erythrocytes and renal tubules. J Biol Chem 263:15634-15642.

Dick E, Miller RF (1985) Extracellular $\mathrm{K}^{+}$activity changes related to electroretinogram components. J Gen Phys 85:885-909.

Dick E, Miller RF, Bloomfield S (1985) Extracellular $\mathrm{K}^{+}$activity changes related to electroretinogram components. II. Rabbit (E-type) retinas. J Gen Physiol 85:911-931.

Dietzel I, Heinemann U, Hofmeier G, Lux HD (1980) Transient changes in the size of the extracellular space in the sensimotor cortex of rats in relation to stimulus-induced changes in potassium concentration. Exp Brain Res 40:423-432.

Dietzel I, Heinemann U, Hofmeier G, Lux HD (1982) Stimulus-induced changes in extracellular $\mathrm{Na}^{+}$and $\mathrm{Cl}^{-}$concentration in relation to changes in the size of the extracellular space. Exp Brain Res 46:73-80.

Dietzel I, Heinemann U, Lux HD (1989) Relations between slow extracellular potential changes, glial potassium buffering, and electrolyte and cellular volume changes during neuronal hyperactivity in cat brain. Glia 2:25-44.

Ecelbarger C, Terris J, Frindt G, Echevarria M, Marples D, Nielsen S, Knepper MA (1995) Aquaporin-3 water channel localization and regulation in rat kidney. Am J Physiol 269:F663-F672.

Echevarria M, Windhager EE, Tate SS, Frindt G (1994) Cloning and expression of AQP3, a water channel from the medullary collecting duct of rat kidney. Proc Natl Acad Sci USA 91:10997-11001.

Finkelstein A (1987) Water movement through lipid bilayers, pores, and plasma membranes, theory and reality. New York: Wiley.

Frigeri A, Gropper MA, Turck CW, Verkman AS (1995) Immunolocalization of the mercurial-insensitive water channel and glycerol intrinsic protein in epithelial cell plasma membranes. Proc Natl Acad Sci USA 92:4328-4331.

Frishman LJ, Yamamoto F, Bogucka J, Steinberg RH (1992) Lightevoked changes in $[\mathrm{K}]_{\mathrm{o}}$ in proximal portion of light-adapted retina. J Neurophysiol 67:1201-1212.

Fushimi K, Uchida S, Hara Y, Hirata Y, Marumo, Sasaki S (1993) Cloning and expression of apical membrane water channel of rat kidney collecting tubule. Nature 361:549-552.

Gardner-Medwin AR (1983a) A study of the mechanisms by which potassium moves through brain tissue in the rat. J Physiol (Lond) 335:353-374.

Gardner-Medwin AR (1983b) Analysis of potassium dynamics in mammalian brain tissue. J Physiol (Lond) 335:393-426.

Gardner-Medwin AR, Nicholson C (1983) Changes of extracellular potassium activity induced by electric current through brain tissue in the rat. J Physiol (Lond) 335:375-392.

Gotow T, Hashimoto PH (1989) Orthogonal arrays of particles in plasma membranes of Müller cells in the guinea pig retina. Glia 2:273-285.

Hasegawa H, Ma T, Skach W, Matthay MA, Verkman AS (1994) Molecular cloning af a mercurial-insensitive water channel expressed in selected water-transporting tissues. J Biol Chem 269:5497-5500.

Haug FMS, Desai VD, Nergaard PO, Laake J, Ottersen OP (1994) Particle-counting in immunogold labelled ultrathin sections by transmission electron microscopy and image analysis. Anal Cell Pathol 6:297.

Haug FMS, Desai V, Laake J, Nergaard PO, Ottersen OP (1996) Widefield digital images in biological transmission electron microscopy (TEM) obtained by automatic image montage [abstract]. In: Proceedings: microscopy and microanalysis 1996 (Bailey GW, Corbett JM, Dimlich RVW, Michael JR, Zaluzec NJ, eds), pp 618-619. San Francisco: San Fransisco Press.

Hildebrand C, Waxman SG (1983) Regional node-like membrane specializations in non-myelinated axons of rat retinal nerve fiber layer. Brain Res 258:23-32.

Hjelle OP, Chaudhry FA, Ottersen OP (1994) Antisera to glutathione: characterization and immunocytochemical application to the rat cerebellum. Eur J Neurosci 6:794-804.

Holthoff K, Witte OW (1996) Intrinsic optical signals in rat neocortical slices measured with near-infrared dark field microscopy reveal changes in extracellular space. J Neurosci 16:2740-2749.

Ishibashi K, Sasaki S, Fushimi K, Uchida S, Kuwahara M, Saito H, Furukawa T, Nakajima K, Yamaguchi Y, Gojobori T, Marumo F (1994) Molecular cloning and expression of a member of the aquaporin family with permeability to glycerol and urea in addition to water expressed at the basolateral membrane of kidney collecting duct cells. Proc Natl Acad Sci USA 91:6269-6273.

Jung JS, Bhat RV, Preston GM, Guggino WB, Baraban JM, Agre P (1994) Molecular characterization of an aquaporin cDNA from brain: candidate osmoreceptor and regulator of water balance. Proc Natl Acad Sci USA 91:13052-13056.

Karwoski CJ, Newman EA, Shimazaki H, Proenza LM (1985) Lightevoked increases in extracellular $\mathrm{K}^{+}$in the plexiform layers of amphibian retinas. J Gen Physiol 86:189-213.

Karwoski CJ, Lu H-K, Newman EA (1989) Spatial buffering of lightevoked potassium increases by retinal Müller (glial) cells. Science 244:578-580.

Kimelberg HK, Frangakis MV (1985) Furosemide- and bumetanidesensitive ion transport and volume control in primary astrocyte cultures from rat brain. Brain Res 361:125-134.

Kimelberg HK, Ransom BR (1986) Physiological and patological aspects of astrocyte swelling. In: Astrocytes (Fedoroff S, Vernadakis A, eds), pp 129-166. New York: Academic.

Knepper MA, Rector Jr FC (1991) Urinary concentration and dilution. In: The kidney (Brenner BM, Rector Jr FC, eds), pp 445. Philadelphia: Saunders.

Laake JH, Slyngstad TA, Haug FM, Ottersen OP (1995) Glutamine from glial cells is essential for the maintenance of nerve terminal pool of glutamate: immunogold evidence from hippocampal slice cultures. J Neurochem 65:871-881. 
Li J-D, Govardovskii VI, Steinberg RH (1994a) Light-dependent hydration of the space surrounding the photoreceptors in the cat retina. Vis Neurosci 11:743-752.

Li J-D, Gallemore RP, Dmitriev A, Steinberg RH (1994b) Lightdependent hydration of the space surrounding photoreceptors in chick retina. Invest Ophthalmol Vis Sci 35:2700-2711.

Lipton P (1973) Effect of membrane depolarization on light scattering by cerebral cortical slices. J Physiol (Lond) 231:365-382.

Lu M, Lee MD, Smith BL, Jung JS, Agre P, Verdijk MAJR, Merkx G, Rijss JPL, Deen PM (1996) The human aquaporin-4 gene: definition of locus and coding to water channel polypeptides in brain. Proc Natl Acad Sci USA 93:10908-10912.

Ma T, Frigeri A, Hasegawa H, Verkman AS (1994) Cloning of a water channel homolog expressed in brain meningeal cells and kidney collecting duct that functions as a stilbene-sensitive glycerol transporter. J Biol Chem 269:21845-21849.

Matsubara A, Laake JH, Davanger S, Usami S, Ottersen OP (1996) Organization of AMPA receptor subunits at a glutamate synapse: a quantitative immunogold analysis of hair cell synapses in the rat organ of Corti. J Neurosci 16:4457-4467.

Nagelhus EA, Lehmann A, Ottersen OP (1993) Neuronal-glial exchange of taurine during hypo-osmotic stress: a combined immunocytochemical and biochemical analysis in rat cerebellar cortex. Neuroscience 54:615-631.

Newman EA (1984) Regional specialization of retinal glial cell membrane. Nature 309:157-159.

Newman EA (1985) Membrane physiology of retinal glial (Müller) cells. J Neurosci 5:2225-2239.

Newman EA (1986) High potassium conductance in astrocyte endfeet. Science 233:453-454.

Newman EA (1987) Distribution of potassium conductance in mammalian Müller (glial) cells: a comparative study. J Neurosci 7:24232432.

Newman EA (1995) Glial regulation of extracellular potassium. In: Neuroglia (Kettenman H, Ransom BR, eds), pp 717-731. New York: Oxford UP.

Newman EA (1996) Regulation of extracellular $\mathrm{K}^{+}$and $\mathrm{pH}$ by polarized ion fluxes in glial cells: the retinal Müller cell. The Neuroscientist 2:109-117.

Newman EA, Reichenbach A (1996) The Müller cell: a functional element of the retina. Trends Neurosci 19:307-317.

Newman EA, Frambach DA, Odette LL (1984) Control of extracellular potassium levels by retinal glial cell $\mathrm{K}^{+}$siphoning. Science 225:1174-1175.

Nielsen S, Agre P (1995) The aquaporin family of water channels in kidney. Kidney Int 48:1057-1068.

Nielsen S, Smith B, Christensen EI, Knepper MA, Agre P (1993a) CHIP28 water channels are localized in constitutively water-permeable segments of the nephron. J Cell Biol 120:371-383.

Nielsen S, DiGiovanni SR, Christensen EI, Knepper MA, Harris HW (1993b) Cellular and subcellular immunolocalization of vasopressinregulated water channel in rat kidney. Proc Natl Acad Sci USA 90:11663-11667.

Nielsen S, Chou CL, Marples D, Christensen EI, Kishore BK, Knepper MA (1995a) Vasopressin increases water permeability of kidney collecting duct by translocation of aquaporin-CD water channels to plasma membrane. Proc Natl Acad Sci USA 92:1013-1017.

Nielsen S, Pallone TL, Smith BL, Christensen EI, Agre P, Maunsbach AB (1995b) Aquaporin-1 water channels in short and long loop descending thin limbs and in descending vasa recta in rat kidney. Am J Physiol 268:F1023-F1037.

Nielsen S, Nagelhus EA, Amiry-Moghaddam M, Bourque C, Agre P, Ottersen OP (1997a) Specialized membrane domains for water transport in glial cells: high-resolution immunogold cytochemistry of aquaporin-4 in rat brain. J Neurosci 17:171-180.

Nielsen S, King LS, Mønster BM, Agre P (1997b) Aquaporins in complex tissues: II. Subcellular distribution in respiratory and glandular tissues of rat. Am J Physiol 273:C1549-C1561.

Nilius B, Reichenbach A (1988) Efficient $\mathrm{K}^{+}$buffering by mammalian retinal glial cells is due to cooperation of specialized ion channels. Pflügers Arch 411:654-660.

Olson JE, Mishler L, Dimlich RVW (1990) Brain water content, brain blood volume, blood chemistry, and pathology in a model of cerebral edema. Acta Neuropathol (Berl) 69:54-65.

Orkand RK, Nicholls JG, Kuffler SW (1966) Effect of nerve impulses on the membrane potential of glial cells in the central nervous system of amphibia. J Neurophysiol 29:788-806.

Orkand R, Dietzel I, Coles J (1984) Light-induced changes in extracellular volume in the retina of the drone, Apis mellifera. Neurosci Lett 45:273-278.

Patil RV, Saito I, Yang X, Wax MB (1997) Expression of aquaporins in the rat ocular tissue. Exp Eye Res 64:203-209.

Paulson OB, Newman EA (1987) Does the release of potassium from astrocyte endfeet regulate cerebral blood flow. Science 237:896898.

Rall W (1977) Core conductor theory and cable properties of neurons. In: Handbook of physiology, Sec 1, Vol 1 (Kandel E, ed), pp 39-97. Bethesda, MD: American Physiological Society.

Ransom BR, Orkand RK (1996) Glial-neruonal interactions in nonsynaptic areas of the brain: studies in the optic nerve. Trends Neurosci 19:352-358.

Ransom BR, Yamate CL, Connors BW (1985) Activity-dependent shrinkage of extracellular space in rat optic nerve: a developmental study. J Neurosci 5:532-535.

Reichenbach A (1991) Glial K ${ }^{+}$permeability and $\mathrm{CNS} \mathrm{K}^{+}$clearance by diffusion and spatial buffering. Ann NY Acad Sci 633:272-286.

Reichenbach A, Nilius B, Eberhardt W (1986) Potassium accumulation by the glial cell membrane pump as revealed membrane potential recording from isolated rabbit retinal Müller cells. Neurosci Lett 63:280-284

Reichenbach A, Henke A, Eberhardt W, Reichelt W (1992) K ${ }^{+}$ion regulation in retina. Can J Physiol Pharmacol 70:S239-S247.

Rohlmann A, Gocht A, Wolburg H (1992) Reactive astrocytes in myelin-deficient rat optic nerve reveal an altered distribution of orthogonal arrays of particles (OAP). Glia 5:259-268.

Sabolic I, Katsura T, Verbavetz JM, Brown D (1995) The AQP2 water channel: effect of vasopressin treatment, microtubule disruption, and distribution in neonatal rats. J Membr Biol 143: 165-175.

Schwarz H, Humbel BM (1989) Influence of fixatives and embedding media on immunolabelling of freeze-substituted cells. Scanning Microsc [Suppl] 3:57-63.

Skoff RP, Knapp PE, Bartlett WP (1986) Astrocytic diversity in the optic nerve: a cytoarchitectural study. In: Astrocytes: development, morphology, andregional specialization of astrocytes (Fedoroff $\mathrm{S}$, Vernadakis A, eds), pp 269-91. Orlando, FL: Academic.

Söderfeldt B, Kalimo H, Olsson Y, Siesjö BK (1981) Pathogenesis of brain lesions caused by experimental epilepsy. Light and electron microscopic changes in the rat cerebral cortex following bicuculli-induced status epilepticus. Acta Neuropathol (Berl) 54:219-231.

Steinberg RH, Oakley II B, Niemeyer G (1980) Light-evoked changes in $[\mathrm{K}]_{\mathrm{o}}$ in retina of intact cat eye. J Neurophysiol 44:897-921.

Svoboda J, Syková E (1991) Extracellular space volume changes in the rat spinal cord produced by nerve stimulation and peripheral injury. Brain Res 560:216-224.

Syková E (1987) Modulation of spinal cord transmission by changes in extracellular $\mathrm{K}^{+}$activity and extracellular volume. Can J Physiol Pharmacol 65:1058-1066.

Syková E (1991) Ionic and volume changes in the microenvironment of nerve and receptor cells. In: Progress in sensory physiology (Ottoson D, ed), pp 1-167. Heidelberg: Springer.

Sztriha L (1986) Time-course of changes in water, sodium, potassium and calcium contents of various brain regions in rats after systemic kainic administration. Acta Neuropathol (Berl) 70:169-176.

Tas PWL, Massa PT, Kress HG, Koschel K (1987) Characterization of an $\mathrm{Na}^{+} / \mathrm{K}^{+} / \mathrm{Cl}^{+}$co-transport in primary cultures of rat astrocytes. Biochim Biophys Acta 903:411-416.

Terris J, Ecelbarger CA, Marples D, Knepper MA, Nielsen S (1995) Distribution of aquaporin-4 water channel expression within rat kidney. Am J Physiol 269:F775-F785.

Terris J, Ecelbarger CA, Nielsen S, Knepper MA (1996) Long-term regulation of four renal aquaporins in rats. Am $\mathrm{J}$ Physiol 271:F414-F422.

Torp R, Hoover F, Danbolt NC, Storm-Mathisen JS, Ottersen OP (1997) Differential distribution of the glutamate transporters GLT1 and rEAAC1 in rat cerebral cortex and thalamus: an in situ hybridization analysis. Anat Embryol 195:317-326.

van Lookeren Campagne M, Oestreicher AB, van der Krift TP, Gispen WH, Verkleij AJ (1991) Freeze-substitution and Lowicryl HM20 embedding of fixed rat brain: suitability for immunogold 
ultrastructural localization of neural antigens. J Histochem Cytochem 83:47-56.

Verbavatz JM, Ma T, Gobin R, Verkman A (1997) Absence of orthogonal arrays in kidney, brain and muscle from transgenic knockout mice lacking water channel aquaporin-4. J Cell Sci 110:2855-2860.

Veruki ML, Wässle H (1996) Immunohistochemical localization of dopamine D1 receptors in rat retina. Eur J Neurosci 8:2286-2297.

Walz W (1987) Swelling and potassium uptake in cultures astrocytes. Can J Physiol Pharmacol 65:1051-1057.

Walz W (1989) Role of glial cells in the regulation of the brain microenvironment. Prog Neurobiol 33:309-333.

Walz W, Hertz L (1982) Oubain-sensitive and oubain-resistant net up- take of potassium into astrocytes and neurones in primary cultures. J Neurochem 39:70-77.

Walz W, Hinks EC (1985) Carrier-mediated KCL accumulation accompanied by water movements is involved in the control of physiological $\mathrm{K}^{+}$levels by astrocytes. Brain Res 343:44-51.

Wasterlain CG, Torack RM (1975) Cerebral edema in water intoxication. II. An ultrastructural study. Arch Neurol 19:79-87.

Yang B, Brown D, Verkman A (1996) The mercurial insensitive water channel (AQP4) forms orthogonal arrays in stable transfected Chinese hamster ovary cells. J Biol Chem 271:4577-4580.

Zeuthen T (1996) Molecular mechanisms of water transport, pp 1-170. Austin, TX: Springer \& Lands. 